\title{
文化自信维度下新时代大学生思想政治教育路径探析
}

\author{
袁丽丽王斌 \\ 唐山学院 \\ D O ::10.32629/jief.v2i1.420
}

[摘 要] 随着我国经济社会的发展建设,我国的教育事业教育理念也发生了根本性的变化。在新的时代传统的高校教育理念必须进行革新发 展，以适应当代大学生的生活和思考方式，使高校教育适应社会发展的需要。高校的思想政治教育问题是高校教育关注的重点问题之一，本 文就将在文化自信的多维度下，对当代高校思政教育的路径进行分析，希望能够给相关教育事业发展提供一些参考和帮助。

[关键词］高校思政教育 ; 文化自信 ; 新时代 ; 路径分析

我国的高校教育发展正在进入新的时代，随着经济和信息技术的发 展, 传统的知识传授方式以及思想教育理念都发生了重大的变革。尤其在 经济开放的大环境下, 高校的思想政治教育内容和方式都收到多样化的冲 击。对此高校教育也必须对教育的方式和内容, 以提升相关教育的质量。 文化自信是我国固有的传统教育理念, 我国在传统文化以及政治文化都有 着先天的特点和优势, 基于此对大学生思想政治教育内容进行调整, 是当 代高校思想教育发展的重要途径。

1 新时代文化自信和大学生思想政治教育的重要联系

文化自信和大学生思想教育建设有着重要的联系, 尤其是在经济高 度发展的当代社会, 思政教育更应该坚持文化自信的教育路径, 促使大学 生在思政思想上建立深刻的认识，使当代思政教育得到新的发展和变革。

1.1 文化自信是促进思政教育发展的有效途径

我国高校有思政教育的传统教育传统，在思想政治教育过程中，通 过对学生的文化自信进行教育和培养是思政教育的重要途径。一方面文化 教育具有模糊性的特点, 从理解文化到相信文化需要一个长期的过程。另 一方面文化具有一定的排他性, 一个人一旦接受了某种文化信仰, 很难对 其信仰的文化进行更改。因此需要文化教育的过程中, 需要对学生的文化 自信进行灌输和培养, 使我国优秀文化占据学生思想的主导地位, 促使学 生对主流文化做到足够的拥护和尊重。值得注意的是, 大学生虽然已经成 为独立个体, 但是社会认识和阅历稍显不足, 尚未形成健全的是非价值观 念, 因此需要进行接收有效的文化培养。另外在新时代文化教育的外部环 境也发生了根本性的变化,对此高校思政教育都必须对文化自信的教育方 式进行个性和强化, 促使思政教育能够适应时代发展的需要 ${ }^{[1]}$ 。

1.2 文化自信是促进国家和社会文化发展的重要内容

大学生是社会中最为活跃的群体之一，是青年人的团体，是国家未 来发展的接班人。因此在高校思政教育中, 通过文化自信教育促使当代年 轻人建立深刻理性的价值观念, 对于社会、国家在未来的发展都有着重要 的价值和意义。文化自信是促进青年人加深对思政教育理念的重要方式, 对于我国传统文化和特色社会主义理念的长远发展都具有重要价值和意 义，对此相关高校应该对思政教育中的文化自信教育建立更深刻的认识， 促进相关教育在国家发展的宏观层面上发挥积极重要的影响。

\section{2 文化自信维度下高校思政教育新途径分析}

高校的思政教育从传统的计划教育制度发展而来，随着社会发展传 统的思政教育方式已经不适用于现代思政教育的发展需要。经济社会的发 展使学生的精神风貌以及获取知识的途径都发生了很大的变化。对此相关 教师应该利用新的教育方式，展开对文化自信维度下，思政教育内容的全 新解读, 研究适应时代发展的教育途径, 使相关思政教育能够合理地发挥 其作用。

2.1 文化自信维度下开展思政教育的创新方式

随着我国教育理念的不断变革发展, 传统的教育理念和现代教育已 经发生了根本性的变化。在以人为本的教育理念指导下, 以及实践性教育 原理, 高校和教师首先应该对教师的教材内容和上课方式进行充分的改 革, 使学生能够对相关课程产生足够的兴趣, 促使学生对高校思政课程保 持积极正确的认识。例如在课程中减少理论内容的阐述, 多增加一些案例、
实例教学, 使学生通过有血有肉的内容, 加深对思政课程的学习和理解。 此外高校思政教育的教师, 也需要对自身的教育方式和理念进行革新。文 化自信教学应该充分的尊重学生的主观能动性, 通过引导式教学促进学生 的思考很理解。应该坚决避免传统的说教式理论教学, 导致学生的反感情 绪增加。最后教师可以利用信息技术发展的便利, 建立师生学习网络小组 等学习群体。通过信息技术增加思政知识的传播和师生之间的交流, 使思 政课程能够更加有效合理的开展, 促使学生对思政课程保持更多的关注和 兴 ${ }^{[2]}$ 。

2.2 加强校园文化建设, 通过校园文化对学生的精神风貌以及爱国主 义情怀进行影响和宣传

高校思政教育过程中, 学生的大量时间在校园内度过, 给相关教育 的有效开展创造了机会。校园文化是高校综合教育质量的重要保证, 是促 进学生个人发展的重要内容。对此文化自信维度的思政教育, 应该充分地 利用校园文化对学生的品行进行潜移默化的影响, 促使学生对相关理念增 加关注和认识。例如学校可以树立一些典型学生、教师榜样, 使学生重视 思政教育的相关活动。学校可以开展一些思政教育征文、评论活动, 使学 生对相关的思政教育保持关注。此外网络上的思政内容宣传, 校园内的宣 传标语等宣传方式, 都能够给思政教育工作带来一定影响。最后在自信教 育方面, 教师可以鼓励学生成立自发的思政教育活动团体, 鼓励学生开展 一些线下的课外交流、参观活动, 促使学生的学习自主性得到体现, 促使 学生对相关思政活动保持兴趣。

2.3 在思政教育过程中充分培养学生的家国责任感

我国是历史悠久的国家，国家统一等气节观念对现代人有着重要的 影响。传统的文化和现代的家国责任感有着共同之处。对此高校思政课程 应该充分的吸收古代优秀文化思想, 着重培养学生的家国情怀等理念, 促 使学生的精神风貌得以有效建立, 充分的践行社会责任精神。值得一提的 是, 社会责任应该表现在学生的精神风貌以及言谈举止上。教师应该避免 教育的内容空洞无力, 导致学生对相关内容表现出茫然的情绪和状态。

3结束语

文化自信维度下新时代大学生思想政治教育是高校教育必须重视和 研究的重要课题, 随着大学教育制度的改革, 大学教育必须给学生提供全 新的教育内容和服务框架体系, 才能促使大学教育适应社会发展的需要, 使大学教育和教育制度下的学生在社会发展过程中贡献出更多作用和力 量。

\section{[参考文献]}

[1]李梦婧.浅析工匠精神与大学生思政教育的融合 [J].决策探索 (下),2020(02):49.

[2]魏苒,邓红伟,张长江.文化自信视域下思想政治教育工作的文化引 领[J].辽宁高职学报,2018(3):110 112.

[3]刘娟.文化自信维度下新时代大学生思想政治教育路径探析 [J].哈 尔滨职业技术学院学报,2019(03):49-51+55.

作者简介：袁丽丽（1983），女，汉族，河北唐山人，硕士，副 教授，研究方向：思想政治教育; 王斌 (1982- ), 女, 汉族, 河北唐 山人, 研究生, 高级政工师, 研究方向 : 思想政治教育。 